\title{
Strategies for developing sustainable design practice for students and SME professionals
}

\author{
A.de Eyto ${ }^{a^{*}}$, M.Mc Mahon ${ }^{b}$, M.Hadfield ${ }^{c}$, M.Hutchings $^{d}$ \\ Special EJEE Issue on SD in Engineering Education
}

\author{
andustrial and Product Design (Dept of Humanities), Institute of Technology Carlow, Ireland* \\ ${ }^{b}$ Department of Manufacturing \& Operations Engineering, University of Limerick, Ireland \\ ${ }^{c}$ School of Design, Engineering and Computing, Bournemouth University, UK \\ ${ }^{d}$ School of Health and Social Care, Bournemouth University, UK
}

\begin{abstract}
Designers and engineers seem finally to be awakening to the challenge that sustainable development has given. Educators and students alike are keenly aware of the need to become more effective in the training and practice of their specific disciplines with respect to sustainability.

In the past four years since this research has developed there has been a marked change in the mass market appeal for sustainable products and services. Implementation of sustainable design practice from both recent graduates and also innovative Small \& Medium Enterprises (SMEs) at a local level is slow. One would assume that the consumer drive would push a change in design practice but perhaps the complexities of sustainable design along with the lack of experience in the field are providing barriers to designers and marketers alike. In addition the SME sector alone makes up the bulk of industry within the European Union (EU) varying in some countries from $80-95 \%$ of the total numbers of companies (Tukker et Al. 2000). These industries by their nature find it difficult to dedicate expertise solely to sustainable development issues. The strategy outlined in this paper intended to introduce concepts of sustainable design thinking and practice to both SMEs and undergraduate students.
\end{abstract}

This current and ongoing research qualitatively assesses appropriate models for educating for sustainable design thinking with Small to Medium Enterprise (SME) employees and undergraduate design students. The sample groups include Industrial Design and Product Design undergraduate students in Ireland at the Institute of Technology, Carlow (IT Carlow), The University of Limerick (UL) and a sample of SME's in the South East of Ireland, with broad national participation from other students of design and professionals from industry. Current levels of understanding of students and SME professionals of key environmental and social issues are measured. Strategies and Mechanisms for improvement of practice in manufacturing and design from a sustainable development perspective are discussed.

Examples of the learning and teaching methods considered include:

- $\quad$ Studio orientated design project based learning modules with specific sustainability briefs being applied.

- Workshop based exercises within the 'Winnovate initiative' (An initiative aimed at improving the New Product Development (NPD) of SME's in the South East of Ireland and West Wales) (Winnovate 2006)

- Joint Day long Seminar formats for students and professionals, mixing professionals and students in both workshop and lecture environments (Reform 2005, 2006, 2007)

Kewords: sustainable design practice, learning strategies, industrial design, SMEs, undergraduates, sustainable products, sustainable product service systems. 


\section{Introduction}

Design has always attempted to merge the practicalities of Engineering, Technology and Business with the subtle elements of Interface, Social concerns and Aesthetic desire. This is currently achievable in most products and services, but without sustainability at its core, neither design, engineering nor technology have the ability to achieve much more than continue to add to the sociological and environmental difficulties of the 21st century.

There is growing evidence (de Eyto et al, 2006) that business has a keen appetite for graduates who have a sustainable literacy as an integral part of their undergraduate skill set. There is also evidence to suggest that businesses are starting to address the lack of capacity in sustainable design practice.

The research outlined here shows how a sample of the current and next generation of designers and business decision makers are slowly developing a range of skills to help them deal with the broad and varied issues around sustainable development. They are taking on the mantle of deciding what key decisions to make regarding the sustainable manufacture and design of consumer products that the world continues to use.

This paper outlines a selection of various methods being applied by the authors in the context of Irish undergraduate design students and SME representatives from the manufacturing sector in Ireland. These methods and educational models were developed following the surveying of these two groups to form a clear idea of prior knowledge and identifying the resultant knowledge gaps. The study includes work with students from all levels of undergraduate study in Industrial and Product Design and includes work undertaken in a multidisciplinary environment with design students, business professionals and business marketing students. The work undertaken by the authors is in the context of PhD level research in to sustainable design education and includes the 'Winnovate' (3.2.1) and 'Reform' (4) initiatives that developed at a regional and national level as a result of collaborations between the authors and their respective academic colleagues and institutes.

It is felt that the methods outlined in the paper, while still in development, may contribute to a wider strategy for introducing and building sustainable design practice for both students and SME professionals in the European context.

\section{Prior Knowledge Survey, Educational Models \& Case Studies}

\subsection{Baseline Survey of Prior Knowledge}

It was important from the start of the research (2003/04) to establish a baseline from which to assess the students and the representatives from the SMEs so the information delivered to them (in whatever format was deemed appropriate) was relevant, practical and above all useful in a professional context.

\subsubsection{Student Survey}

The students in this case were all studying Industrial Design on the undergraduate honours degree course at IT Carlow or Product Design and Technology at the UL. A prior knowledge survey using a modified version of the sustainable development questionnaire developed by Surrey University (Azapagic, 2001) for the Royal Academy of Engineering (RAE) was used to assess different student groups' understanding of key issues surrounding sustainable development and design.

The questions fell under the following themes:

- Environmental legislation, policy and standards.

- Environmental tools, technologies and approaches.

- General environmental issues.

- The rating of the students' importance of sustainable design as an issue to themselves, their work and the community as a whole.

The student prior knowledge survey findings indicated that:

- The students were aware in the main about topical environmental and social issues such as recycling, global warming and depletion of natural resources. The levels to which they could explain these issues in depth may be limited.

- $\quad$ The students have an understanding of the issues around design and manufacture for sustainability however they are not familiar with key words and descriptions and find it difficult to 
differentiate between the more subtle elements such as cradle to grave rather than Cradle-toCradle (Mc Donnagh \&Braungart, 2002) design philosophy and process.

- A clear majority of students in all the classes assessed felt that sustainable design was of significant importance to them as individuals, the companies they may end up working for and the world as a whole

\subsubsection{SME Survey}

The SME study group consists of 15 small companies in the South East of Ireland who were involved with the 'Winnovate Program' . The Industrial Design Dept. at IT Carlow ran the program in partnership with the National Centre for Product Design \& Development Research (PDR) in Wales from 2004-2006 (The initiative was aimed at improving the new product development potential of SMEs in the South East of Ireland and West Wales) (Winnovate,2006). There was an opportunity through the Sustainable Design element of the brief for this program to complete a similar prior knowledge survey of the company's current levels of understanding of the key Sustainability issues.

The SMEs involved work in the manufacturing and NPD fields. None of the companies had at that stage developed a Sustainable Design specialism. In fact for many of the companies involved it was a first engagement with 'Design' in a formal sense. The key representative's from the companies were given the questionnaires before their participation in the Sustainable Design Workshop and follow up interviews (Post Program) were conducted as part of the ongoing research.

The broad assessment of the findings of the prior knowledge survey concluded the following:

- By contrast (with the students) the professional experience emphasized knowledge, appreciation, and recognition of sustainable design and development based on practice considerations.

- The SMEs in the main have a slightly more practical knowledge of the social and environmental issues, as one would expect however there was limited appreciation for the relevance of the issues to their work.

- As with the students they have an appreciation for the Design for Sustainability issues generally but are not familiar with the key phrases and descriptions used by the experts in the field.

- All the companies recognise the need for their products to become more sustainable in nature but predominantly due to legislative pressures.

\subsection{Educational Models}

\subsubsection{Problem Based Learning}

It is critical that students (in this case students mean both undergraduates and Business professionals) undertaking Continuous Professional Development (CPD) are encouraged to apply the knowledge skills and competencies that they acquire in third level or in industry. Educational models have been developed over the past 50 years which endeavour to capture the process experiential learning (Kolb 1984) and engage students with higher level learning outcomes (Bloom 1956). It is from these foundations that the learning and teaching strategies described were developed. It has long been acknowledged that Problem Based Learning (PBL) animates the process of business and research and so as an educational method it deserves a large place in any curriculum, (Hutchings et al, 2007). PBL allows the student or group of learners the possibility of fully applying their research; problem solving; concept generation; creative and organisational skills, in a holistic manner when dealing with a given challenge (Boud \& Feletti, 1998). The process often encourages students to work with the complexity of the problem, recognising there are no single solutions and identifying multiple solutions. Creativity and lateral thinking are critical skills for all disciplines to learn. This often requires radical approaches to the learning and teaching process that allow students and educators alike to have the space to develop new thinking. Innovation in learning as well as research is all important in addressing the SD issues.

"Innovation requires, divergent thinking before convergent thinking" (Rhea 2003).

\subsubsection{Collaborative Multidisciplinary Learning.}

Mixed discipline groups, cross-departmental and experiential groups from different academic and industrial levels are needed to allow for a more holistic approach to problem solving (de Werk \& Mulder 2004). The Issues surrounding sustainable development are extremely complicated with most specialists dealing their areas of expertise rather than the big picture. Hence there is a danger that in the third level sector that students receive detailed analysis of specifics without being able to achieve joined up thinking as a final skill. The continuing focus on disciplinary learning is critical on one hand as it ensures specialism in areas such as design, engineering, marketing and architecture. However the 
reality is that all these professionals will continue to rely heavily on team driven work in their professional lives. So it is critical that we, as educators, expose students to other disciplines and facilitate multidisciplinary learning through project work in the main curricula (See Reform 4)

"Learning to share: to imagine that any one closed group could solve the complex problems we face today is folly. The free and open software movements promise to overcome our territorial attitudes and take advantage of our collective potential." (Mau et al 2004).

\subsubsection{Live Projects}

Live projects (projects involving business people, SMEs, larger companies as well as Non Governmental Organizations (NGOs) allow students to get a taste of reality in a controlled environment whilst giving companies a chance to explore areas they may not necessarily have the luxury to do normally. These require intensive management from academic staff and work best in a studio/ project/ tutorial type format again using group work. The experience of the recent "Winnovate" project at IT Carlow, Ireland has been that companies and students can work to mutual benefit when both parties come together to learn something new.

\section{Case studies}

\subsection{Undergraduate Student Case Studies}

\subsubsection{Integrated holistic approach at IT Carlow}

In this case study from 2005 the Winnovate Project SMEs were offered the option of collaborative work with a fourth year Industrial Design (ID) student at ITCarlow through the vehicle of their major project. As both the companies and the students in question were involved with the Reform seminar of 2005 the Sustainability issues were fresh in their minds at the time the work was commencing.

The students were asked to build, through their normal Honors Degree Project (HDP) work, a sustainability philosophy from concept, through research all the way to detailed design for manufacture, assembly and disassembly. From a Sustainable Design perspective this is the ideal model, i.e.

considering all the aspects of a new product development with the sustainability of the product and service system as core elements from the start rather than as 'end of pipe' additions

It is not possible to outline all the outcomes of each of these projects but of the 32 projects all the students were able, with varying degrees of success, to develop their conceptual designs in to realistic solutions which showed high levels of eco-innovation and sustainable thinking.

Environmental, Social and Economic considerations were key but in conjunction with aesthetic and user centered forms and functions. Some of the student works included a high focus on sustainable materials selection. The use of the recently acquired CES edu pac (Cambridge Engineering Selector) (Granta Design, 07) proved a practical addition to the standard background knowledge of materials. For the first time in many HDPs it was apparent that students were using specific Bio-polymers (for end of life considerations), Aluminum alloys (for weight reduction to increase efficiency and reusability), Forestry Stewardship Council (FSC) certified timbers in furniture and home wares, Low or no Volatile Organic Compound (VOC) lacquers and finishes, Water based and Sintered coatings on metals rather than high solvent based alternatives. The selection of power sources for some of the products proved interesting with Bio-Diesel engines, Photo Voltaic (PV) Solar chargers and re-chargeable systems being considered in place of conventional methods.

Many of the final solutions included attempts to address the social considerations of the product from manufacturing through to innovative suggestions on the sale and distribution of the products. Leasing rather than the owning of some products was considered to allow for responsible maintenance and extended life or to encourage product take back possibilities.

The students themselves chose to highlight the Sustainable Design thinking of the HDPs through their end of year public exhibition which they titled "Design for a Sustainable Future". To highlight this each student dedicated part of their presentation board to a short paragraph with their own Sustainable Design philosophy with respect to the concept and their own professional thinking. The philosophies in the main were well justified and the students ability to defend their thinking was an interesting outcome of the study.

As outlined previously 15 of the 32 projects were undertaken as "Live projects" with the second round SMEs from the south east of Ireland as a final outcome from the Winnovate program. The students who elected to work in collaboration with an SME gained real practical and effectively experienced the constraints and realities of a client/consultant relationship under the guidance of the lecturers. From a 
Sustainable design perspective this meant that the student and the client had to consider practical, realistic solutions with an ideological input from the start.

\subsubsection{Modular specific approach at University of Limerick (UL)}

The approach adopted at $U L$ the differed slightly in that the students (final year 2007-2008) were given a formal Design for Sustainability module as part of their core teaching. This module took the format of lectures from a variety of experts as well as practical projects and coursework. The outcomes however, were very similar to the IT Carlow experience when it came to the choosing and design of their Final Design Project in their graduating year. The considerations of sustainable design principles have become an inherent part of their work and are now included at every stage of the design process with some students even choosing to explore the design and development of services and Product Service Systems (PSS's) instead of 'conventional' products.

Should the students in both institutes carry this or a similar philosophy towards their work practice in industry there will be a sea change in thinking as they influence their co-workers and companies. The ideal scenario being that these designers would ensure policy change on a management level to allow the sustainability agenda to be placed at the heart of industry practice.

\subsection{SME Case Studies}

\subsubsection{Winnovate SME Sustainable design workshop}

The 2004 'Winnovate' workshop on sustainable design included a short presentation on some of the key considerations around sustainable design and an introduction of the concepts surrounding the use of materials and mixing of materials in the manufacture of any given product. The workshop was run over an afternoon session with a 20-minute presentation and a 3-hour long dismantling and discussion exercise in 'round table' format. The main element of the workshop involved a Product Dismantling Exercise using an electric kettle as a case study. The exercise provided the companies with a focus on which to develop their discussions around the key issues.

The main areas discussed included:

- Materials usage (Environmentally Sustainable pros and cons of various plastics, metals, solvents and packaging options)

- Materials mixing and separation post use, sourcing of materials and manufacture from third country locations and the ethical and quality issues involved. The current Waste Electronic \& Electrical Equipment directive (WEEE) and Restriction of Hazardous Substances (RoHS) EU directives along with other waste minimization and legislative issues were discussed at this stage.

- Opportunities for re-design of the product. The kettle provided many obvious areas for improvement and re-design both radical and superficial. The companies were surprisingly creative when given free reign in considering viable alternatives.

The informal nature of the workshop style and the discursive environment works well with companies who are willing to take time out of their busy schedules to participate. All the company representatives commented on how valuable it was to be off site for only a few hours exploring opportunities and creative solutions with relative strangers. It provides them with the space necessary to stand back and assess the business they are involved with and how it might be improved either from a new product development perspective or through improving their existing product lines.

\section{Multidisciplinary Seminars}

\section{1 'Reform' Initiative}

The Reform initiative was developed by two of the authors from IT Carlow and UL in conjunction with the Cultivate Centre, Dublin. It is divided into two parts; a series of one -day seminars (held in October 2005, Nov 2006 and Nov 2007) and secondly a number of third level workshops in the design courses not directly specialising in Sustainable Design (The National College of Art and Design (NCAD),Dublin and Institute of Technology(IT),Sligo . The ReForm seminars intended to introduce the topic to both students and business in Ireland and to spark the Sustainability dialogue amongst students industry and experts. Anecdotal research showed that a conference/seminar of its type had not been held in Ireland prior to this. The workshops in the other design courses provided an opportunity to develop capacity outside of the courses the authors are directly involved with. 
The Reform seminars aim to be an introductory session to the main principles, philosophies and strategies in Sustainability with a particular focus on "Design for a sustainable future". They bring together key national and international experts ${ }^{(2)}$ with representatives from various SMEs in Ireland, in addition students from the main Product and Industrial undergraduate courses in the country are invited to participate alongside of the ITCarlow and UL Students. The format for the seminar encourages the interaction of the mixed Student groups and Industry representatives through discussion workshops that are interwoven with the key speakers' presentations. The objective is to expose the students to the difficult realities of Sustainable Design from an Industry perspective and for the company representatives to avail of some of the creative and more idealistic freethinking of the students.

The expert lectures combined with the targeted workshops allowed the participants to be immersed in Sustainable Design thinking for a full day, to share ideas and to understand the challenges and opportunities they faced.

Note2: The specific Speakers to date have included: Alastair Fuad-Luke (author of the Eco-Design Handbook), Dr.Dorothy Maxwell (then director of the Environmental Policy Unit of Enterprise Ireland), Dr. Paul Butler (Materials Ireland) Dr. Frank O'Connor and Simon O'Rafferty (Eco Design Unit, Wales), Ab Stevels (Philips), Prof. Ezio Manzini (Milan Polytechnic), Gertjan de Werk (TU Delft), Simon Stringer (Leif Environmental), Erik van Lennep (Tepui Design)

The key observations from the Reform seminars that are applicable to the research include the following:

- The Students and SMEs engage well with a short format seminar on the basis that they can devote full concentration to the issues being discussed.

- The Seminar /Workshop format allows for broad and specific topics to be introduced in quick succession and for the participants to rapidly form philosophies, action points, and obvious case study parallels for their own work.

- The Seminar speakers if carefully chosen can provide a varied diet of ideology, experience and practical advice in a short time period. Often this knowledge would take much longer to acquire through other sources of learning.

- The difficulties include the fact that the participants can come away from a Seminar day full of idealism and new enthusiasm for Sustainable design but this can rapidly dissipate when they are challenged with the practical application of the theories to their every day work (as can be seen in the findings from graduate interviews).

It was noted at the end of the three seminar days that a need existed for a clear follow up plan for targeted work with participants after the seminar (this has been facilitated through the workshop days at NCAD and IT Sligo). Also the professionals asked for access to additional learning resources more focused on their needs as practicing designers.

\section{Follow on Study of students}

For the purposes of assessing the effectiveness of the learning strategies outlined previously, three graduates from the class described in 3.1.1 were involved with this study were interviewed. These interviews assessed their current work in industry and the attitudes of their employers towards sustainable development and design. The graduates work in three radically different areas of Industry and reflect the varied fields that design graduates find work in. Table 1 outlines some of the responses from those interviews. 


\begin{tabular}{|c|c|c|c|}
\hline Interview Questions & $\begin{array}{l}\text { Design Engineer, } \\
\text { (Farm Machinery) }\end{array}$ & $\begin{array}{l}\text { In House Designer, } \\
\text { (Medical Training } \\
\text { Devices) }\end{array}$ & $\begin{array}{l}\text { 3D Visualisation Designer, } \\
\text { (Construction Engineering) }\end{array}$ \\
\hline $\begin{array}{l}\text { Did the specifics of your HDP } \\
\text { (honours degree project) } \\
\text { Iportfolio influence your } \\
\text { employment? }\end{array}$ & $\begin{array}{l}\text { Yes both had an } \\
\text { influence, they were } \\
\text { very impressed with my } \\
\text { portfolio and the } \\
\text { relevance of the project } \\
\text { to my line of work also } \\
\text { helped me. }\end{array}$ & $\begin{array}{l}\text { Just the fact that I had } \\
\text { worked on a live } \\
\text { project for my HDP } \\
\text { was key }\end{array}$ & $\begin{array}{l}\text { Yes, The fact that I had a } \\
\text { portfolio really impressed } \\
\text { them, there was that wow } \\
\text { factor, also the detail of the } \\
\text { HDP work was above their } \\
\text { expectations }\end{array}$ \\
\hline $\begin{array}{l}\text { What is your current } \\
\text { thinking/understanding about } \\
\text { sustainable design? }\end{array}$ & $\begin{array}{l}\text { Feel that it is important } \\
\text { but I would be more } \\
\text { realistic about what I } \\
\text { can influence. }\end{array}$ & $\begin{array}{l}\text { It was what I wrote my } \\
\text { thesis on and I still } \\
\text { think about it but have } \\
\text { no real opportunity to } \\
\text { put it in to practice }\end{array}$ & $\begin{array}{l}\text { More realistic about what can } \\
\text { be achieved, decisions made } \\
\text { at the start of a project make } \\
\text { a big difference }\end{array}$ \\
\hline $\begin{array}{l}\text { Does the fact that you studied } \\
\text { SD as part of your course } \\
\text { influence your decision } \\
\text { making in your current work? }\end{array}$ & $\begin{array}{l}\text { Yes it is something I } \\
\text { think about but find } \\
\text { difficult to implement }\end{array}$ & Yes and No, & $\begin{array}{l}\text { Yes, it allows me to } \\
\text { communicate with the } \\
\text { engineers and architects in a } \\
\text { more confident and probing } \\
\text { manner }\end{array}$ \\
\hline $\begin{array}{l}\text { Has your perspective } \\
\text { changed with time (the } \\
\text { idealism of being a student } \mathrm{V} \\
\text { the realism of employment } \\
\text { and dealing with } \\
\text { clients/employer)? }\end{array}$ & $\begin{array}{l}\text { As a student you are } \\
\text { more naïve about what } \\
\text { you can produce, the } \\
\text { realism of the working } \\
\text { world makes you less } \\
\text { idealistic. }\end{array}$ & $\begin{array}{l}\text { College does not } \\
\text { prepare you for fast } \\
\text { time lines and the } \\
\text { rapid pace of } \\
\text { development in } \\
\text { Industry. }\end{array}$ & $\begin{array}{l}\text { Yes but the company have a } \\
\text { positive approach to nurturing } \\
\text { new employees. }\end{array}$ \\
\hline $\begin{array}{l}\text { Can you describe the attitude } \\
\text { of your employer towards } \\
\text { sustainability, if any? }\end{array}$ & $\begin{array}{l}\text { It is not explicitly } \\
\text { discussed except form } \\
\text { an economic and health } \\
\text { and safety point of view }\end{array}$ & $\begin{array}{l}\text { None, it does not even } \\
\text { get discussed }\end{array}$ & $\begin{array}{l}\text { Very positive, at the top of } \\
\text { their public profile and at the } \\
\text { forefront of developing new } \\
\text { strategies and guidelines for } \\
\text { construction industry globally }\end{array}$ \\
\hline $\begin{array}{l}\text { Is there a notion of Product } \\
\text { Life Cycle Thinking (LCT) in } \\
\text { the design work that you are } \\
\text { involved with? }\end{array}$ & $\begin{array}{l}\text { Yes, the service that the } \\
\text { company provides to } \\
\text { customers is important } \\
\text { and the product has an } \\
\text { extended life as a result. }\end{array}$ & $\begin{array}{l}\text { Yes, the products get } \\
\text { serviced and we have } \\
\text { upgrade options for } \\
\text { our customers }\end{array}$ & $\begin{array}{l}\text { Yes but more in terms of } \\
\text { Energy usage of facilities and } \\
\text { embodied energy in materials } \\
\text { etc }\end{array}$ \\
\hline $\begin{array}{l}\text { How does your company } \\
\text { approach New Product } \\
\text { Development (NPD)? }\end{array}$ & $\begin{array}{l}\text { Modularity for ease of } \\
\text { service and customer } \\
\text { needs are important }\end{array}$ & $\begin{array}{l}\text { The current product } \\
\text { has had a lot more } \\
\text { investment in terms of } \\
\text { research and } \\
\text { attempting to make it } \\
\text { multifunctional }\end{array}$ & $\begin{array}{l}\text { In the traditional large project } \\
\text { design sense, } \\
\text { Multidisciplinary teams, } \\
\text { briefings etc. }\end{array}$ \\
\hline $\begin{array}{l}\text { Is local manufacture a priority } \\
\text { for your company, Is Local } \\
\text { procurement an issue (for } \\
\text { components or services? }\end{array}$ & $\begin{array}{l}\text { Yes the family are still } \\
\text { very involved and are } \\
\text { keen for various reasons } \\
\text { to keep manufacture } \\
\text { and procurement local }\end{array}$ & $\begin{array}{l}\text { Yes, Local } \\
\text { manufacture helps us } \\
\text { keep an eye on quality } \\
\text { and is easier to } \\
\text { manage for us. }\end{array}$ & $\begin{array}{l}\text { Yes even though we are a } \\
\text { global player local } \\
\text { procurement and labor are } \\
\text { important as they help with } \\
\text { quality control }\end{array}$ \\
\hline $\begin{array}{l}\text { Is Sustainability a priority in } \\
\text { your companies work? }\end{array}$ & $\begin{array}{l}\text { Not explicitly. The } \\
\text { company } \\
\text { Philosophy is more } \\
\text { about end-product } \\
\text { quality and efficiency. }\end{array}$ & No & $\begin{array}{l}\text { Yes at the top of the agenda } \\
\text { going forward }\end{array}$ \\
\hline $\begin{array}{l}\text { Is Sustainability identified as } \\
\text { a concern for your } \\
\text { customers? }\end{array}$ & $\begin{array}{l}\text { It is a growing concern } \\
\text { but not top of the list. }\end{array}$ & No & $\begin{array}{l}\text { Yes, More and more clients } \\
\text { are expecting sustainable } \\
\text { solutions }\end{array}$ \\
\hline $\begin{array}{l}\text { Do you or your company see } \\
\text { Sustainability as a tool for } \\
\text { Commercial advantage? }\end{array}$ & Not at present. & No & $\begin{array}{l}\text { Yes it is one of the reasons } \\
\text { the company is a world leader } \\
\text { in the field of construction }\end{array}$ \\
\hline
\end{tabular}

(Note 1: all answers are paraphrased for editing purposes but every attempt has been made to give a true reflection of the sentiment of the answers, the interviewees and their company names are removed for confidentiality purposes) 
The qualitative follow on study of the Graduates from IT Carlow concluded the following:

- The graduates are influenced greatly by the constraints of their specific employers and their ability to apply their sustainable design skills and competencies can be greatly limited or enhanced depending on the focus of the company.

- There is an obvious need for company 'buy in' with respect to sustainable design and development. Graduates will not change the culture of a business on their own.

- The sustainable design education that the students engaged with has in the main influenced their employers and the practice of the teams that they work with. Often this is in small incremental ways but as the graduate's progress their influence will grow also.

\section{Conclusions}

The research outlined here is a small sample of a suite of models, initiatives and case studies that continue to be developed by the authors and their academic and industry colleagues.

This paper outlines two nuanced approaches (through the case studies 3.1.1 \& 3.1.2) taken within the course syllabi in the context of the undergraduate student work. IT Carlow on one hand has made an attempt to weave sustainable design theory and practice in to all levels of the syllabus which culminates in their HDP final work. UL on the other hand has chosen to be more explicit in the focusing of sustainable design in to a specific module which is then reflected in their HDP work.

On reflection it was found that both approaches are valid and allow for significant learning gains for the students. In both cases the authors feel there is a need to research further the effectiveness of the methods. It is apparent that students need to develop a broad sustainable literacy throughout their education and yet often this can get lost in the overall syllabus without sustainability focused modules or projects.

There is a need to constantly review learning and teaching methods and curriculum content for Sustainable Design as the "market" for graduates and sustainable business practitioners is constantly shifting. In the past employers did not expect any sustainable thinking from graduates, currently they are aware of the need for it but in the future one would expect employers to demand it as a mandatory addition in their graduate skillset.

This research will continue to develop Sustainable Design learning strategies for Undergraduates and SME's to build capacity for sustainable design thinkers in industry. Never before has the opportunity for designers been so obvious in terms of finding an influential space at the product development table. Sustainable Design may be the key 'Trojan Horse' which allows design graduates and design thinkers to find space to change, for the better, the services and products which society depends on socially, environmentally and economically.

The relationship between the Reform initative and the more formal undergraduate learning and teaching approach is complex. The undergraduate students who experienced the integrated holistic approach benefit from a more realistic and applied approach, dealing with complex problems. The modular specific approach benefits student development of in depth knowledge of sustainability. The professional practitioners benefit from the process of working with the students as they experience the holistic and philosophical approach brought to sustainable design practice. 


\section{Biographies}

Adam de Eyto is a Lecturer at the Institute of Technology, Carlow, Ireland on the Industrial Design and Product Design Innovation programs. He is currently completing a PhD with Bournemouth University researching multidisciplinary sustainable design education. He has a BDes in Industrial Design from NCAD and has worked in industry as both an in house designer and a consultancy designer. He acts as an advisor to Design Ireland Skillsnet and is co-developing a sustainable design practice CPD module for design professionals.

deeytoa@itcarlow.ie

Muireann McMahon is a Junior Lecturer at the University of Limerick, Ireland on the BSc in Product Design + Technology. She has a degree in Industrial Design from The NCAD and an MSc in Sustainable Design from Bournemouth University. She has taught on design courses (Industrial and Product) in Ireland, the UK and New Zealand.

muireann.mcmahon@ul.ie

Professor Mark Hadfield (BEng, PhD, CEng, FIMechE, FHEA) Deputy Dean: Research and Enterprise at the School of Design, Engineering and Computing at Bournemouth University, United Kingdom. He is also the co-director of Sustainable Design Research Centre at Bournemouth University. He is the academic champion for a Royal Academy of Engineering project at Bournemouth aimed at integrating sustainable development issues within the teaching curriculum.

mhadfield@bournemouth.ac.uk

Maggie Hutchings is a Senior Lecturer in Education in the School of Health and Social Care at Bournemouth University and Programme Leader for the Masters in Health and Social Care Education. Her interests are in promoting and supporting pedagogical scholarship with particular research interests in e-learning and interprofessional education. She has a BA in Social Sciences from the University of East Anglia, an MA in Information Studies from Sheffield University, and has recently completed a PhD examining the contribution of online learning environments to learning in higher education at the University of Southampton. She is a Fellow of the Higher Education Academy. mhutchin@bournemouth.ac.uk 